Discussion Paper No. 01-51

\title{
Timing of International Market Entry of UK and German High-Tech Start-Ups
}

Oliver Bürgel, Andreas Fier, Georg Licht and Gordon Murray

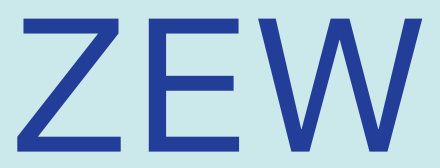

Zentrum für Europäische Wirtschaftsforschung GmbH

Centre for European Economic Research 



\section{NON-TECHNICAL SUMMARY}

High-tech markets are highly internationalized and competition and industry structures are global in scope. Hence, even young firms have to enter foreign markets early in their life. Companies which belong to the life science sector or to the information and communication industries meets international clients and competitors all around. Based on a survey of about 600 German and British startup companies, the paper looks at the time structure of young firms' entries into international markets. We use an 'event history analysis' to analyse the relationship between technological sophistication and the speed of new product introductions by start-up companies. First, we find that $70 \%$ of the firms had internationalised after eigth years of existence. Second, the international experience of the founder(s) increases the speed of foreign market entries. In summary the timing of internationalisation is a dynamic process which is influenced by initial human capital endowment, permanent R\&D activitiy, the products' innovativness and learning effects of day to day activities. 

Discussion Paper No. 01-51

\title{
Timing of International Market Entry of UK and German High-Tech Start-Ups
}

\author{
Oliver Bürgel, Andreas Fier, Georg Licht, Gordon Murray
}





\title{
Timing of International Market Entry of UK and German High-Tech Start-Ups
}

\author{
by \\ Oliver Bürgel, Gordon Murray \\ London Business School \\ Andreas Fier, Georg Licht \\ Centre for European Economic Research
}

\begin{abstract}
We examine the impact of technological product advantages, prior international experience of the management, firm size and age, country differences, and sunk costs as determinants of the timing of international market entry. The timing of internationalisation is analysed using 'event history analysis' for 600 British and German start-up companies in high-technology industries. The results indicate that the incidence of internationalization increases over time. For the majority of new firms the question is not whether the firm will internationalize but when. The analyses indicated that a high commitment to $\mathrm{R} \& \mathrm{D}$ fosters rapid internationalization. The involvement of founder managers who are internationally experienced increases the speed of foreign market activity. Working against rapid internationalization was a high level of product customization. The findings suggest that timing of internationalization is a dynamic process which is influenced by initial human capital endowment, technological advantages, and learning from of day to day activities.
\end{abstract}

Keywords: start-ups, high-technology industries, internationalisation

JEL Class: L 21, L 60, F 23

Acknowledgements: Financial support from the Anglo-German Foundation for the Study of Industrial Society, Apax Partners \& Co. Ventures Ltd. and the Department of Trade \& Industry (UK government) is gratefully acknowledged. The authors would also like to recognise the valuable contribution of Gregor Frieb and Juliane Lauer in preparing the data for the analysis and for the final reading. All errors of fact and/or omission remain solely to the responsibility of the named authors. 



\section{Introduction}

One important dimension of the process of internationalisation is the timing of entry. It is often maintained that high-tech markets are highly internationalised. Competition and industry structures are global in scope. Therefore, even young firms have to enter foreign markets early in their life in order to enhance their competitiveness and to expand output. In so doing they gain from economies of scale or the participation in the development of the dominant technology design, etc.

Despite the crucial importance of the timing decision of theoretical literature on the timing of foreign market entry by young SMEs is scare. Buckley and Casson (1981) looked at the choice between licensing, exporting and foreign direct investment. They state that the timing of entry is primarily affected by the rate of growth of the market. However, profits from internationalisation are uncertain. Modelling uncertainty in the context of market entry is introduced by Dixit (1989). His theoretical model claims that uncertainty delays the timing of market entry. But the validy of this argument can be challenged in the context of new technology based firms (NTBFs). Here, the contrary-argument that the delay in market entry increases uncertainly could be made with equal validity. More recently, Rivoli and Salorio (1996) and Chi and McGuire (1996) discuss the strategic perspectives of the timing of investment locating it within a transaction cost approach. They also considered 'learning effects' as an influence on foreign market entry. Pennings and Sleuwaegen (1998) have also dealt with the relationship between uncertainty and the timing of entry.

In this paper, we analyse the time structure of foreign market entry by looking at technological advantages, prior international experience of the management, firm size and age, and indicators of sunk costs as determinants of the decision to enter international markets. First, we shortly point to the theoretical framework of our analyses. Then, we give some hints to the data used in this study and the employed empirical methodology. The timing of international market entry is described using event history analyses. We explain the probability of foreign market entry using a multivariate hazard function framework. In addition, we split our sample into firms which enter the international market immediately after start up (Born Internationals), firms which enter international markets later (Late Internationalisers) and firms which are not international but plan to enter an international market in the near future (Non Internationalisers). Finally, we summarise the main results and highlight implications for international entrepreneurship. 


\section{Theoretical Framework}

The theoretical underpinnings of the time structure of international market entry are quite similar to those arguments which are expected to explain the occurrence of internationalisation (see Oviatt and MacDougall 1994 for a survey). Two theoretical approaches are especially attractive to explain the timing of international market entry. First, internationalisation process models which comprise stage models focus on the timing of internationalisation. Second, resource-based theories also offer prescription of the internationalisation process which are relevant to small hightechnology firms.

The internationalisation stage models concentrates on the managerial aspects of internationalisation. Timing of market entry, is seen as functions of the increasing experience and subsequently greater commitment of managers to foreign markets (Johanson and Vahlne 1977, 1990). A basic assumption is that firms have to deal with additional costs and uncertainties when entering a foreign environment. These are caused by, for example, material differences in the business culture, language, market structures etc. According to Johanson and Vahlne, firms overcome these disadvantages by gaining direct experiential knowledge of foreign markets over time. The experience can result from generalisation of experience from other markets exhibiting similar conditions. According to this view, a firm starts its internationalisation in markets with the lowest perceived uncertainty (or lowest economic distance) and low entry costs. Hence, stage models implies that the likelihood of internationalisation is increasing in the age of a firm. Moreover, we should also expect that management's experience in an international business environment or education abroad speed up internationalisation.

Resource-based approaches ( $R B V$ ) hold that a firm can generate higher rents from the utilisation of firm specific assets which cannot be replicated by other firms. These rents can then be used to offset the higher costs of competing abroad. RBV emphases on the mechanisms of how resources, skills and capabilities are generated, accumulated and deployed. Based on Penrose's notion of the firm as a bundle of assets, the resource-based view of the firm argues that organisational performance is a function of the internal assets of a firm. If these resources are matched appropriately to the external environment, then the firm may command a competitive advantage over its rivals. Resources include both physical resources and intangible resources. While the former can be more easily obtained and imitated, it is 
especially the latter that differentiate a firm from its rivals. They include management skills, brand names, unique processes, organisational culture and the tacit knowledge of employees. International activities would then be determined by the resources and capabilities that a firm possesses and that allow it to overcome the initial costs of competing in foreign environments. Alternatively, the costs of internationalisation could be lowered as a result of the deployment of resources, knowledge and capabilities that facilitate the internationalisation process. So, we should expect that firms with more specific resources like internationally experienced management and technological innovative products are more likely to internationalise early.

\section{The Data}

One important aim of our study was to analyse the internationalisation of start-ups with a relatively large sample of firms utilising a comparable basis of selection in two different countries, because we believe that results are more reliable when data from firms with different national backgrounds are employed. The data have been used in previous studies to analyse the occurrence and degree of internationalisation as well as the impacts of early internationalisation on firm's growth (e.g. Bürgel et al. 1998, 2000). Hence, remarks on the data can be quite sparse.

The Questionnaire: Our data were generated through a mail survey using an identical questionnaire in both countries. The questionnaire asks for data to proxy 'transaction costs' during the sales process and proxies for situation in which high transaction might occur, for information on the international experience of the founder(s), and for characteristics of their firm including details of the goods and services produced as well as the resources devoted to product and process development.

Definition of High-tech Start-ups or New Technology Based Firms (NTBFs): A high-tech start-up is defined as being a legally independent company which is no older than ten years and operates in a high-technology sector(s) (see Table 1). We use the list of high-technology sectors established by Butchart (1987) to determine the relevant sectors in manufacturing. In addition, we include selected R\&D-intensive service industries.

Data Sources and Sampling Frame: We use sampling frames generated from similar data sources in both countries. Sampling was based on firms operating in the industries defined above, which had at least three employees in 1997, and that had been founded between 1987 and 1996. To identify 
those firms, we used data from the leading credit-rating agencies in both countries (Dun \& Bradstreet in the UK and Creditreform in Germany). Data are stratified by sector and firm size.

The Survey: The mail survey resulted in 232 usable questionnaires for Germany and 362 for the UK. We calculated weights for each strata taking into account the inclusion probability and the response probability. The inclusion probability accounts for the bias introduced through the deliberate over- or under-sampling due to the stratified random sampling process. It is calculated by dividing the number of firms by the number of firms in the cleaned Dun \& Bradstreet and Creditreform samples per strata (at least 521 observations). Therefore, strata specific weights are calculated as the inverse of the product of inclusion probability and response probability per strata.

\section{Modelling the Timing of Entry Using Hazard Functions}

Before presenting the empirical results, we will briefly describe the basic assumptions and the methodological background of our empirical approach. The advantage of using event-history analysis or duration data models in the present context is that it takes account of both the occurrence and the timing of an event while estimating the effects of exogenous factors. We consider the internationalisation of a firm as an event that may or may not occur at any time during the life of the firm. We ignore the entry mode chosen and assume that the determinants of timing of internationalisation is independent of the entry mode type.

'Event history analysis' or 'economic duration' models are well established constructs in labour economics. Both have previously been used to model firm survival (see, e.g. Agarwal 1998, Audretsch and Mahmood 1995, Mata and Portugal 1994). Schoonhoven et al. (1990) have used event history models to look at the relationship between technological sophistication and the speed of new product introductions by start-up firms. Tan and Vertinsky (1996) use event history analysis to model the timing of foreign market entry via FDI of large Japanese multinationals into the US and Canadian market.

There are two situations in which a firm will fail to have internationalised in our sample. First, some of the firms founded in a given year will not be observed to have internationalised because these firms had already died before our sampling took place. This type of failure ('survivor bias') cannot be observed using our sample. However, it is open to dispute whether this will result in a severe problem for the generalisation of our 
results because it is not obvious whether internationalising or non internationalising firms will die earlier. The second type of 'failure' (i.e. not having experienced the event of internationalisation) is observed if the company does not have international sales before the end of our observation period. However, the firm may start international sales in the future. This particular instance is known as 'censoring' in the hazard rate literature.

Timing of internationalisation is measured in years since the foundation year. Time zero represents the initial year in which the firm was started. For 'right-censored' firms, i.e. not yet internationalising, we cannot observe this event but we do record the time since start-up until the end of the observation period. One modelling approach would be to take the time between start-up and the occurrence of the internationalisation event or, conversely, the end of the study period as the dependent variable of interest. However, we adopt an alternative modelling approach, which looks at the conditional probability (the hazard rate $\lambda$ ) that a firm has international sales in a given year $t$ conditional that the firm did not have international sales in the year $t-1$.

In our sample, the starting points of the firms are not all in the same year. The length of time for which individual firms remain purely domestic can be the same irrespective of different start up dates. Therefore, the endogenous variable is specified not in real time but in 'spell length', i.e. the time foregone since start-up.

The probability distribution of the duration (the time of staying domestic) can be specified by the distribution function $F(t)=\operatorname{Pr}(T<t)$ which specifies the probability that the time $T$ - the time period since start-up before a firm enters the international market - is less than some value $t$. The corresponding density function is $f(t)=d F(t) / d t$. The 'survivor function' depicts the share of the 'population' which remains at time $t$ in the starting state (e.g. firm purely active on the domestic market). The survivor function is given by $S(t)=1-F(t)$. Consequently, $\mathrm{F}(\mathrm{t})$ can be interpreted as the share of the population which internationalised until time $t$. The hazard function can then be written in terms of the unconditional probability and density functions as $\lambda(t)=f(t) / S(t)$. This describes the probability that internationalisation will occur at time $t$ given that it had not occurred up until time $t$.

In the empirical literature on hazard functions (see Kiefer 1988 for a survey), two functional forms are widely used. The exponential distribution uses the unconditional probability $F(t)=1-\exp (-\lambda t)$ where $\lambda$ 
is a parameter larger than zero. This approach assumes that the hazard rate is constant over time, e.g. the chance of having the first international sales in the year $t$ is constant over the lifetime of a firm. More flexibility is added to the specification when we use the Weibull distribution which generalises the exponential model. The hazard rate of the Weibull distribution is given by $\lambda=\gamma \alpha t^{\alpha-1}$, which corresponds to the exponential model if $\alpha=1$. If $\alpha>1$, the hazard rate is increasing in $t$, e.g. the chance of international sale increases the older a firm gets, and decreases if $\alpha<1$. Note that the time dependence does not depend on the value of the parameter $\gamma$. In addition to this parametric modelling, we also employ the Cox's partial likelihood approach to account for individual heterogeneity.

\section{Describing the Timing of First International Sales}

A useful starting point for the analysis is to look at the empirical distribution of the hazard rate and the cumulative probability function for having international sales until the year $t$ since start-up. Let $n_{j}$ be the number of firms in our sample which have or have not experienced international sales before duration $t, h_{i}$ is the number of firms which have started international sales before time $t$ and $m_{i}$ is the number of firms which have not yet experienced international sales until time $t$. The empirical hazard function is then given by:

(1) $\hat{\lambda}\left(t_{j}\right)=h_{j} / n_{j}$ where $n_{j}=\sum_{i \geq j}^{T}\left(m_{i}+h_{i}\right)$

which is the number of internationalised firms at time $t$ divided by the number of firms 'at risk' at duration $t_{j}$. The corresponding number for the share of firms with international sales after $t$ years of lifetime is then:

(2) $\hat{\Lambda}\left(t_{j}\right)=\sum_{i \leq j} \hat{\lambda}\left(t_{i}\right)$

This is the well-known Kaplan-Meier or product-limit estimator. A plot of both functions by country is given in Figure 1. Figure 1 shows that the hazard rates are more or less stable during the first five years of the existence of the firms in our sample. The sharp drop in the German case during year six is probably due primarily to the small sample size in this year. It should not be interpreted as a drop in the hazard rate. Differences between countries occur in some years but not in others. Germany seems to 
have a lead in the first years but the hazard rate decline over time. However, the difference between Germany and the UK is not statistical significant as revealed by a likelihood-ratio test on the homogeneity of the hazard function. This test gives a value of 1.62 with 1 degree of freedom. The lower panel of Figure 1 shows that the cumulative share of firms with international sales follows a more or less similar expansion path in both countries. However, some care should be taken when attempting to draw conclusions from simple univariate frameworks.

\section{Determinants of Timing of International Market Entry}

The specification of the determinants of the hazard rate in the multivariate model (i.e. the probability of starting international sales in a given year after start-up) is based on rationales stemming from the stage models as well as resource based view. In addition, we account for variables capturing the transaction cost and the uncertainty involved in international business. Hence, we take into account:

- country-specific differences

- product characteristics which affect sunk entry costs (e.g. consumer good, ready-to-use product)

- transaction-specific fixed costs including those resulting from the specific customisation of products. These costs are also a form of sunk entry costs

- technology-related competitive advantages which are captured by the degree of R\&D activities and by the characteristics of the product (e.g. technological novelty)

- factors relating to the human capital and experience of a firm including team size, management's experience in an international environment prior to foreign market entry, evidence of skill shortages at the time of start-up, and firm size

- industry-specific differences which capture various costs and advantages of international sales

We estimate two alternative specifications of a hazard rate model. First, we estimate a non-parametric Cox regression. The Cox model without an exogenous variable collapses to the Kaplan-Meier estimator used above. Secondly, we allow the hazard rate to vary over time by using a Weibull regression model which is, therefore, a straight forward test of stage models. 
Given the short time period available, we restrict the time dependency to be either positive or negative and omit a more complex modelling approach. The estimation results are reported in Table 2.

Time Dependency of Probability for Starting International Sales: What should be noted first is that the probability of entering foreign markets increases with the length of the time period in which a firm has remained purely in the domestic market. This can be seen from the shape parameter of the Weibull model which is significantly larger than one. When taking into account various factors highlighted by the resource-based approach to internationalisation, we find that staying in the domestic market has some positive effect on the subsequent ability to compete internationally. Even after controlling for the determinants of the probability to internationalise, we find a positive impact. This hints at important learning effects (legitimacy, management, etc.) which improve the likelihood of entering international markets. Note however, that our observation period is quite short. So, it may well be the case that this positive time dependence is valid only in the first years. Note that, allowing for the hazard rate to change over time does not change the parameter estimates significantly. We obtain nearly the same results when we assume either a constant hazard rate (exponential regression model) or a proportional hazard rate approach (Cox regression).

Country Differences: West German firms internationalise more rapidly than either East German or British firms. This finding probably reflects the closer links of the German economy to its neighbouring countries (e.g. Austria, Switzerland, France): It also is in line with lower transaction and country-specific sunk entry costs (e.g. German firms can serve the Austria markets without changing the product description).

Industry Effects: Our estimates also reveal some inter-industry differences. Engineering, medical equipment and pharmaceutical firms in general access international markets earlier. This effect is probably best thought of as an indication of low, industry-specific sunk entry costs. An alternative explanation might be to assume that the typical products of firms in these industries serve small national markets. This, in turn, makes rapid internationalisation more attractive by spreading fixed costs across a larger aggregate sales volume. However, we did not see significantly larger sales growth rates for internationalisers in these industries compared to non internationalisers, or compared to internationalisers in other industries. Therefore, we find the above interpretation of low, industry-specific sunk entry costs the more plausible explanation. 
Firm Size: Firms which are larger at start-up internationalise more quickly than firms starting from a smaller size. Therefore, well resourced firms are better able to bear the sunk entry cost associated with international market entry.

Nature of Technology: Technological advantage also encourages a more rapid internationalisation path. We find significant positive effects of both occasional and permanent R\&D activities on the speed of internationalisation. This finding is also corroborated in the UK sample by the variable indicating the innovative nature of the technology of the main product.

Know-how and Experience of the Management Team: International experience either abroad or in a multinational enterprise (MNE) turns out significantly to accelerate the process of internationalisation. This result can be interpreted in two ways. Greater international experience is frequently indicative of widespread, personal networks. This is in line with the network approach to internationalisation put forward e.g. by Coviello and Munro 1995. According to this theory, existing contacts can be utilised to access new foreign customers. However, it can also be argued that managers with international experience face lower cost in accessing information on foreign markets. Thus, this effect can further support the sunk entry cost argument.

In addition, shortages of managerial resources in the sales or distribution functions of firms slow down the process of foreign market entry. Therefore, not only specific experience in foreign market but also the general set of operational abilities of the founding team prior to internationalisation seem to affect the rate of development of internationalisation. The quality of a start-up (in terms of management abilities) plays a crucial role in encouraging the internationalisation process.

Product Characteristics: The customisation of a product demands significant technical experience, effective communication and tight networks, as well as an integration of customers into the product design process. These characteristics imply large, sunk entry costs and higher running costs of international sales than those experienced by firms selling non-customised goods. Critically, customisation also imposes significant limitations on the ability to exploit scale economies. The findings confirm our ex ante expectations that customisation inhibits the internationalisation process. Sunk entry costs are also an explanation for the slower internationalisation path which was found for consumer goods and ready-touse products. This is because selling these kinds of products requires larger 
investment in intangibles before sales occur (e.g. marketing, distribution networks). Again, this result indicates the material effect of substantial, fixed entry costs.

\section{Checking the Sensitivity of Results: Timing of Internationalisation as a Result of Management's Discrete Choice}

An alternative way of looking at the timing of internationalisation is to interpret the time path taken as the direct result of strategic management decisions. We thus assume that internationalisation is part of the strategy of a firm and the consequence of a set of decisions made immediately after incorporation. To model the time structure of foreign market entry as a decision result, we distinguish between four different outcomes of this decision. The four possible choices of the firms are:

- entering the market within a year after start-up or in the year of their first sale (Born internationals)

- entering foreign markets within the observation period but not in the first year (Late internationalisers)

- planning international sales in the future

- no foreseeable plans for international sales

Such an outcome of a simultaneous decision process corresponds well to a multinomial logit model (see Greene 1997 for a description). The main advantage of this modeling strategy is that it allows to check whether the influence of exogenous factors change over time.

In essence, the results of the multinomial logit model (see Table 3 ) are fully in line with those of the hazard rate models. Some new insights appear due to the separate treatment of firms planning to internationalise in the near future and those which do not expect international sales in the foreseeable future. In general, those variables which turned out previously to be important factors in increasing or slowing down the speed of the internationalisation process had less significance for firms which despite their declared intentions had not yet started the internationalisation process. However, certain differences between the groups of firms planning to internationalise and the firms not planning to internationalise remain significant. 
Given the similarity of the results between the different models, we will only highlight some additional insights gained with the alternative modelling approach. Again, we find that technological advantages and founders' prior experience of international markets foster the speed - and therefore also the probability - of international sales. However, it seems that initial endowment variables lose some of their importance over the life time of the firm. Therefore, 'learning-by-doing' from day-to-day business activity gains weight as a source of experience which helps firms to enter international markets. This seems to be the most crucial difference between the born international firms and firms which have not yet started to engage in international business. Interestingly, when looking at the would-be internationalisers compared to the purely domestic firms, we find a positive significant effect of occasional R\&D but not a significant positive effect of permanent $R \& D$. This is in line with the interpretation that permanent $R \& D$ speeds internationalisation. Firms devoting regularly resources to R\&D have an advantage in quickly developing international markets. However, this potential advantage disappears over time when there is no successful international activity.

The positive effect a larger starting size has on international sales appears to erode over time. The same is true with respect to experience prior to start up which also seems to have a declining effect over time on the internationalisation process. On the other hand, this erosion appears to have a desirable outcome in the case of the penalty of intense customisation of products on internationalisation. Intense customisation slows down the internationalisation process but this negative effect get smaller over time.

Finally, inter-industry differences in the rates of internationalisation are most significant when looking at the early phase of the process. In later years, inter-industry differences become less important. Similarly, the advantages West German firms have with regard to entering foreign markets also seem to diminish over time.

\section{Summary and Discussion}

This paper describe international market entry as a dynamic process which is influenced by the initial human capital endowment, the products' technological characteristics, and the positive learning effects of day-to-day business activity. The results indicate quite categorically that the incidence of internationalisation increases over time. Our data demonstrates that, by the eight year of existence, $70 \%$ of the sample firms had internationalised 
regardless of their country of origin. For the majority of NTBFs the question is not whether the firm will internationalise but when.

The analyses indicated that the older the business and the more regular the commitment to $\mathrm{R} \& \mathrm{D}$, the more rapid the development of international sales. The involvement of founder managers who have worked abroad or for a multinational company also increases the speed of foreign market activity. However, the influence of educational experience abroad is not statistically significant. Working against rapid internationalisation was the (high) level of product customisation. The production of end-user rather than capital good type products also appears to work against rapid internationalisation.

The findings suggest that timing of internationalisation is a dynamic process which is influenced by initial human capital endowment, permanent $\mathrm{R} \& \mathrm{D}$ activity, the products' innovative technological characteristics, and the learning effects of day to day activities. The power of these variables to influence the timing of internationalisation, however, erodes over time. Thus, for example, the ability of product customisation to reduce the speed of internationalisation also diminishes over time.

This give rise to the conclusion that our cross-section survey observes firms at a point in time during an ongoing process. The share of internationalisers represents just a snapshot. We should expect that this process will continue for some time. This, in turn, implies that in the long run the share of internationally active firms in high-tech industries will be even larger than the share observed by our study's snapshot. We can therefore conclude that it is essential for the economic success of the majority of high-tech start-ups that they conquer international markets sooner or later.

We should also keep in mind that our sample primarily consists of extremely high-tech and R\&D intensive firms. Given these firm characteristics, the differences found with regard to the product technology and $R \& D$ variables seem even more remarkable. Put another way, these differences would be even more obvious were firms from low-tech industries taken as the benchmarks. Innovative technology endowments appear to be one of the driving forces behind the rapid internationalisation of start-ups firms.

The initial endowments of the founders are also an important prerequisite for early internationalisation. This is especially important with regard to the founder management's international business experience. However, learning processes from day-to-day domestic businesses activity 
can, over time, compensate in part for the founders not having international experience prior to start-up. Hence, it is extremely important for the founders of NTBFs to get some experience of international businesses prior to starting their own high tech enterprises. This experience is likely to be of substantial benefit in helping to improve the short run performance of the firm during the most critical phase of NTBF's life cycle - i.e. the first seven years. 


\section{Appendix}

Table 1: Definition of High-Tech Industries

\begin{tabular}{|c|c|c|}
\hline $\begin{array}{l}\text { Aggregated } \\
\text { industries }\end{array}$ & $\begin{array}{l}\text { NACE } \\
\text { Rev. } 1\end{array}$ & Short description according to NACE Rev.1 \\
\hline $\begin{array}{l}\text { R\&D intensive } \\
\text { service } \\
\text { industries }\end{array}$ & $\begin{array}{l}64.20 ; 72.20 \\
72.30 ; 72.40 \\
72.60 ; 73.10\end{array}$ & $\begin{array}{l}\text { Telecommunication, Computer Programming and Software } \\
\text { Services, Data Processing, Misc. Computer Services, R\&D } \\
\text { in Natural Sciences and Engineering }\end{array}$ \\
\hline ICT-Hardware & $\begin{array}{l}30.01 ; 30.02 \\
32.20 ; 32.30\end{array}$ & $\begin{array}{l}\text { Office Equipment; Computers and other Information } \\
\text { Processing Equipment; Television and Radio Transmitters } \\
\text { and Apparatus for Telephony and Telegraphy; Television } \\
\text { and Radio Receivers, Sound or Video Recording and } \\
\text { Reproducing Apparatus }\end{array}$ \\
\hline $\begin{array}{l}\text { Engineering } \\
\text { Industries }\end{array}$ & $\begin{array}{r}33.20 ; 33.30 \\
33.40\end{array}$ & $\begin{array}{l}\text { Electronic Instruments and Appliances for Measuring, } \\
\text { Checking (except Industrial Process Control); Electronic } \\
\text { Industrial Process Control Equipment; Optical Instruments; } \\
\text { Photographic Equipment }\end{array}$ \\
\hline $\begin{array}{l}\text { Health and } \\
\text { Life Sciences }\end{array}$ & $\begin{array}{r}24.41 ; 24.42 \\
33.10\end{array}$ & $\begin{array}{l}\text { Pharmaceutical Products and Preparations; Medical and } \\
\text { Surgical Equipment and Orthopaedic Appliances }\end{array}$ \\
\hline $\begin{array}{l}\text { Miscollaneous } \\
\text { High-tech } \\
\text { manufacturing }\end{array}$ & $\begin{array}{l}24.16 ; 24.17 \\
31.10 ; 31.20 \\
32.10 ; 35.30\end{array}$ & $\begin{array}{l}\text { Plastics and Synthetic Rubber in Primary Form; Electric } \\
\text { Motors, Generators and Transformers; Electricity } \\
\text { Distribution and Control Apparatus; Electronic Valves, } \\
\text { Tubes and other Components; Aircraft and Spacecraft } \\
\text { Manufacturing }\end{array}$ \\
\hline
\end{tabular}


Table 2. Hazard Function Results for the Timing of Internationalisation

\begin{tabular}{|c|c|c|c|c|c|c|}
\hline \multirow[b]{2}{*}{ Exogenous variables } & \multicolumn{2}{|c|}{ Cox regression - } & \multicolumn{2}{|c|}{ Exponential regression } & \multicolumn{2}{|c|}{ Weibull regression } \\
\hline & Coeff. & $\begin{array}{l}\text { mptotic } \\
\text { values }\end{array}$ & Coeff. & $\begin{array}{c}\text { Asymptotic } \\
t \text {-values }\end{array}$ & Coeff. & $\begin{array}{c}\text { Asymptotic } \\
t \text {-values }\end{array}$ \\
\hline West-Germany & 0.6856 & 2.96 & 0.6841 & 2.95 & 0.7735 & 2.69 \\
\hline East-Germany & 0.3053 & 1.23 & 0.3188 & 1.29 & 0.4122 & 1.38 \\
\hline ICT-Hardware & 0.2580 & 1.70 & 0.2650 & 1.74 & 0.2858 & 1.57 \\
\hline Engineering & 0.3864 & 2.50 & 0.3865 & 2.50 & 0.4230 & 2.26 \\
\hline Bio/Med/Life & 0.4610 & 2.81 & 0.4587 & 2.78 & 0.5270 & 2.59 \\
\hline Other Industries & 0.2333 & 1.57 & 0.2317 & 1.55 & 0.2441 & 1.37 \\
\hline Log(No. employees start up) & 0.2002 & 3.11 & 0.1973 & 3.09 & 0.2239 & 2.79 \\
\hline R\&D occasionally & 0.4042 & 1.87 & 0.4095 & 1.90 & 0.5164 & 2.08 \\
\hline R\&D permanent & 0.4875 & 2.25 & 0.4853 & 2.24 & 0.5366 & 2.14 \\
\hline R\&D intensity & -0.0003 & -0.17 & -0.0001 & -0.06 & 0.0001 & 0.03 \\
\hline \multicolumn{7}{|l|}{ Product technology UK } \\
\hline New combin. of exist. tech & 0.3006 & 1.59 & 0.3088 & 1.63 & 0.3267 & 1.46 \\
\hline New tech. devel.. elsewhere & 0.4448 & 2.05 & 0.4541 & 2.11 & 0.5017 & 1.95 \\
\hline New tech. devel. in-house & 0.3550 & 1.91 & 0.3614 & 1.94 & 0.3765 & 1.70 \\
\hline \multicolumn{7}{|l|}{ Product technology FRG } \\
\hline New combin. of exist. tech & -0.0836 & -0.34 & -0.0784 & -0.32 & -0.1026 & -0.33 \\
\hline New tech. devel.. elsewhere & -0.4030 & -1.32 & -0.4052 & -1.32 & -0.4585 & -1.28 \\
\hline New tech. devel. in-house & -0.1532 & -0.67 & -0.1525 & -0.66 & -0.2141 & -0.74 \\
\hline Experience abroad & 0.2717 & 2.53 & 0.2753 & 2.57 & 0.3227 & 2.42 \\
\hline Experience in MNU & 0.4379 & 4.38 & 0.4500 & 4.54 & 0.5531 & 4.49 \\
\hline Education abroad & 0.0544 & 0.38 & 0.0504 & 0.35 & 0.0526 & 0.29 \\
\hline \multicolumn{7}{|l|}{ Shortage in competencies } \\
\hline Sale/Marketing & -0.1006 & -1.85 & -0.0939 & -1.73 & -0.1050 & -1.58 \\
\hline Production/R\&D & -0.0790 & -1.07 & -0.0821 & -1.12 & -0.1142 & -1.30 \\
\hline Intense product customisation & -0.4318 & -3.59 & -0.4317 & -3.57 & -0.5234 & -3.57 \\
\hline Consumer good & -0.2168 & -1.29 & -0.2196 & -1.31 & -0.2139 & -1.08 \\
\hline Ready to use product & -0.2662 & -2.63 & -0.2692 & -2.67 & -0.3263 & -2.65 \\
\hline \multicolumn{7}{|l|}{ Shape-Parameter } \\
\hline $\log (\alpha)$ & & & & & 0.3565 & 10.72 \\
\hline$\alpha$ & & & & & 1.43 & \\
\hline \multicolumn{7}{|l|}{ Summary statistics: } \\
\hline No of observations & \multicolumn{2}{|c|}{521} & \multicolumn{2}{|c|}{521} & \multicolumn{2}{|c|}{521} \\
\hline$\chi^{2}$ against constant only & \multicolumn{2}{|c|}{131.13} & \multicolumn{2}{|c|}{137.78} & \multicolumn{2}{|c|}{123.09} \\
\hline Log. Likelihood & \multicolumn{2}{|c|}{-1993.15} & \multicolumn{2}{|c|}{-606.24} & \multicolumn{2}{|c|}{-576.31} \\
\hline
\end{tabular}

Source: LBS/ZEW 
Table 3: Born Internationals, Late Internationalisers, Planing to Internationalise vs. Domestic Firms: Results Using a Multinomial Logit Approach

\begin{tabular}{|c|c|c|c|c|c|c|}
\hline \multirow[b]{2}{*}{ Exogenous variables } & \multicolumn{2}{|c|}{ Born internationals } & \multicolumn{2}{|c|}{$\begin{array}{c}\text { Late } \\
\text { internationalisers }\end{array}$} & \multicolumn{2}{|c|}{$\begin{array}{c}\text { Expecting } \\
\text { international sales }\end{array}$} \\
\hline & Coeff. & $\begin{array}{l}\text { Asympt. } \\
t \text {-values }\end{array}$ & Coeff. & $\begin{array}{l}\text { Asympt. } \\
t \text {-values }\end{array}$ & Coeff. & $\begin{array}{l}\text { Asympt. } \\
\text { t-values }\end{array}$ \\
\hline "West-Germany & 2.05 & 2.97 & 1.75 & 2.66 & 1.29 & 1.78 \\
\hline East-Germany & 0.17 & 0.24 & 0.93 & 1.49 & 1.06 & 1.59 \\
\hline ICT-Hardware & 0.71 & 1.36 & 0.25 & 0.49 & -0.27 & -0.51 \\
\hline Engineering & 1.65 & 2.51 & 1.44 & 2.28 & 0.58 & 0.87 \\
\hline Bio/Med/Life & 2.27 & 2.48 & 2.01 & 2.24 & 1.26 & 1.38 \\
\hline Other Industries & 0.61 & 1.27 & 0.42 & 0.94 & -0.23 & -0.49 \\
\hline Log(No. Employees start up) & 0.81 & 3.31 & 0.57 & 2.39 & 0.23 & 0.93 \\
\hline $\log ($ Age $)$ & & & 1.30 & 3.47 & -0.32 & -0.90 \\
\hline R\&D occasionally & 0.73 & 1.36 & 0.36 & 0.74 & 0.85 & 1.69 \\
\hline R\&D permanent & 1.12 & 2.10 & 1.01 & 2.10 & 0.70 & 1.29 \\
\hline \multicolumn{7}{|l|}{ Product technology UK } \\
\hline New combin. of exist. tech & 2.21 & 3.68 & 2.07 & 3.58 & 2.25 & 3.67 \\
\hline New tech. devel.. elsewhere & 1.91 & 2.67 & 1.50 & 2.12 & 1.41 & 1.91 \\
\hline New tech. devel. in-house & 2.82 & 3.38 & 2.39 & 3.68 & 2.46 & 3.54 \\
\hline \multicolumn{7}{|l|}{ Product technology FRG } \\
\hline New combin. of exist. tech & -0.53 & -0.55 & 0.30 & 0.35 & 0.78 & 0.88 \\
\hline New tech. devel.. elsewhere & -1.74 & -1.70 & -0.65 & -0.83 & 0.40 & 0.52 \\
\hline New tech. devel. in-house & 0.27 & 0.35 & 0.55 & 0.76 & 0.73 & 0.95 \\
\hline Experience abroad & 1.28 & 3.02 & 1.14 & 2.75 & 0.85 & 1.94 \\
\hline Experience in MNU & 1.38 & 3.37 & 1.18 & 2.98 & 0.67 & 1.59 \\
\hline Education abroad & 1.27 & 1.64 & 1.00 & 1.32 & 0.86 & 1.13 \\
\hline \multicolumn{7}{|l|}{ Shortage in competencies: } \\
\hline Sale/Marketing & -0.04 & -0.19 & 0.09 & 0.44 & 0.33 & 1.58 \\
\hline Production/R\&D & -0.12 & -0.47 & 0.05 & 0.18 & 0.03 & 0.13 \\
\hline Intense product customisation & -1.99 & -3.99 & -1.06 & -3.02 & -0.66 & -1.85 \\
\hline Consumer good & -0.88 & -1.58 & -1.57 & -2.75 & -0.59 & -1.08 \\
\hline Ready to use product & -0.50 & -1.34 & -0.56 & -1.58 & -0.06 & -0.17 \\
\hline Constant & -3.61 & -3.57 & -4.43 & -4.42 & -1.53 & -1.57 \\
\hline \multicolumn{7}{|l|}{ Summary Statistics } \\
\hline No of observations & \multicolumn{6}{|c|}{516} \\
\hline$\chi^{2}$ against constant only & \multicolumn{6}{|c|}{256.49} \\
\hline Log. Likelihood & \multicolumn{6}{|c|}{-554.98} \\
\hline
\end{tabular}

Note: The reference group is those firms which do not expect int. sales in the foreseeable future Source: LBS/ZEW 
Figure 1: Hazard Rates for Internationalisation and Estimated Share of Internationalised Firms

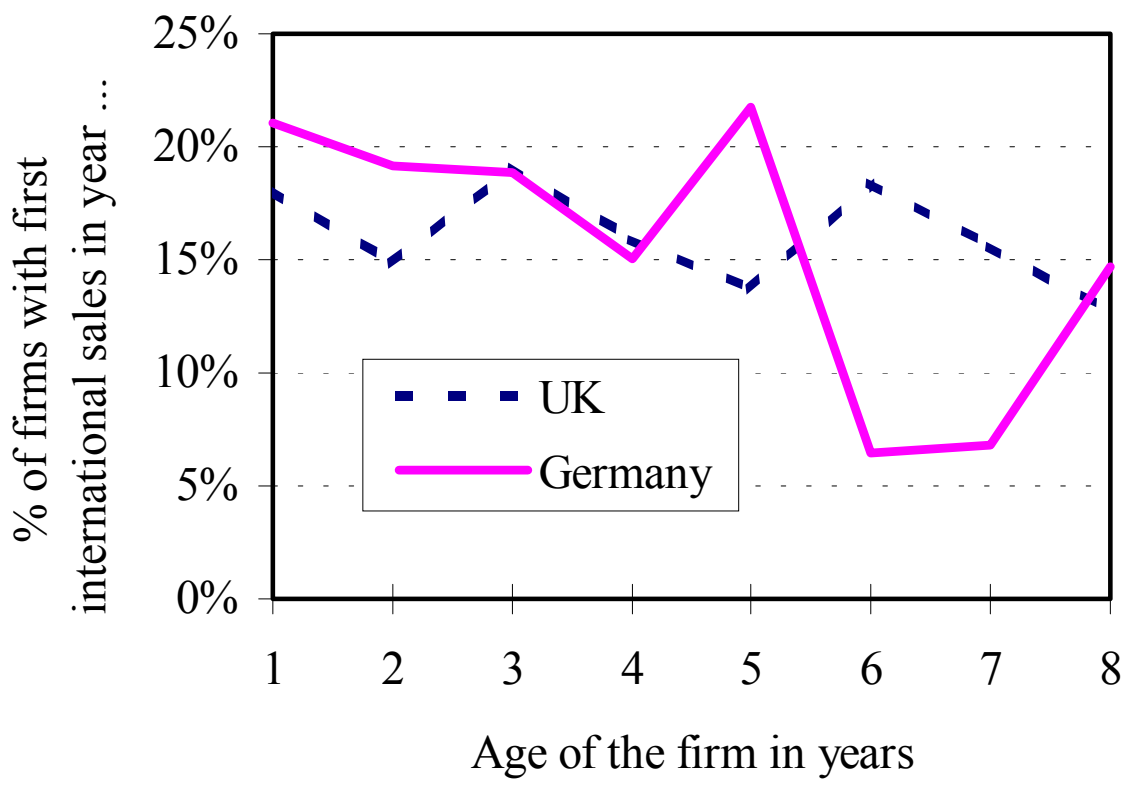

Source: LBS/ZEW; Weighted data

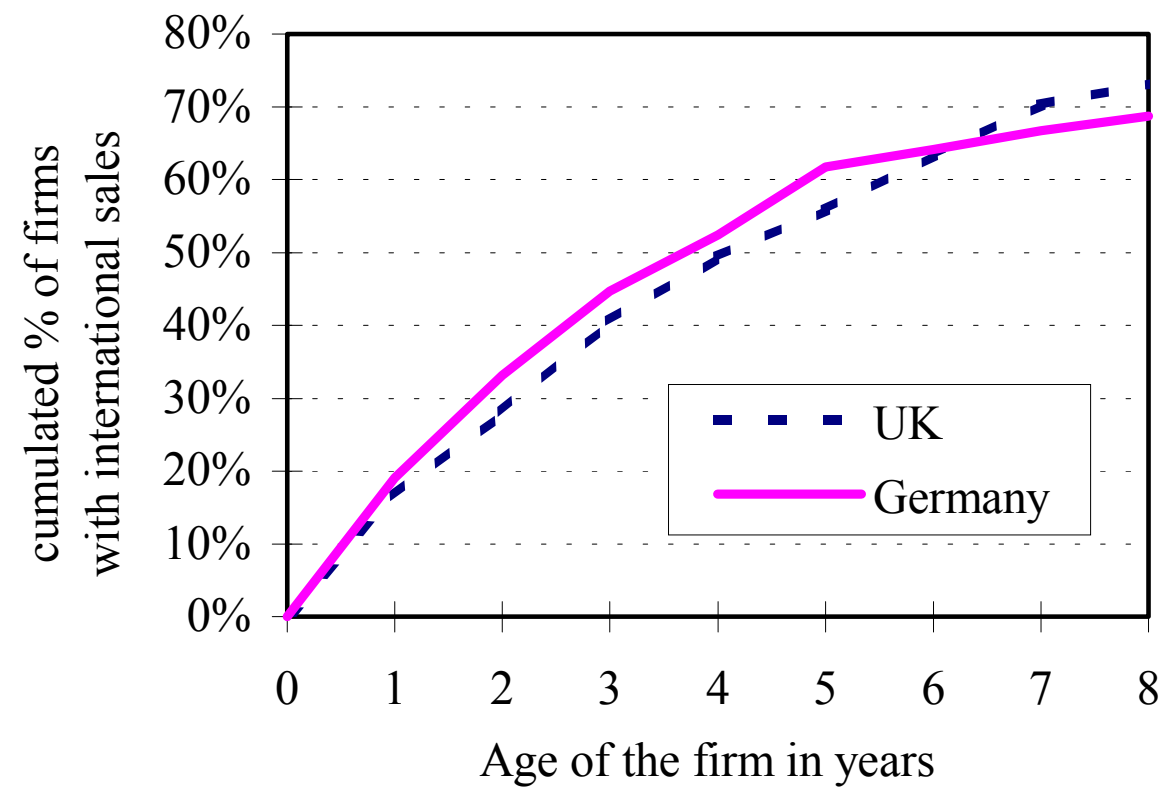

Source: LBS/ZEW; Weighted data 


\section{References}

Agarwal, R. (1998), Small Firm Survival and Technological Activity, Small Business Economics, 11, 215-224.

Audretsch, D. B. and T. Mahmood (1995), New Firm Survival: New Results using a Hazard Function, Review of Economics and Statistics, 76, 97-103.

Buckley, P. J. and M. Casson (1981), The Optimal Timing of a Foreign Investment, Economic Journal, 91, 75-87.

Bürgel, O, A. Fier, G. Licht and G. Murray (2000) Internationalisation of High-Tech Start-ups and Fast Growth - Evidence for UK and Germany, ZEW Discussion Paper No. 00-35, Mannheim.

Bürgel, O, A. Fier, G. Licht, G. Murray, and E. Nerlinger. (1998), The Internationalisation of British and German Start-Up Companies in HighTechnology Industries. ZEW Discussion Paper No. 98-34, Mannheim.

Butchart R. (1987), A new UK definition of high-technology industries, Economic Trends, 400, 82-88.

Chi, T. and D. J. McGuire (1996), Collaborative Ventures and Value of Learning: Integrating the Transaction Cost and Strategic Perspectives on the Choice of Market Entry Modes, Journal of International Business Studies, 27, 285-307.

Coviello, N. E., and H. J., Munro (1995), Growing the entrepreneurial firm: Networking for international market development, European Journal of Marketing, 29(7), 49-62.

Dixit, A. K. (1989), Entry and Exit Decisions under Uncertainty, Journal of Political Economy, 97, 620-638.

Greene, W. H. (1997), Econometric Analysis, $3^{\text {rd }}$ edition, New York. 
Johanson, J., and J.-E. Vahlne (1977), The internationalization process of the firm - A model of knowledge development and increasing foreign market commitment, Journal of International Business Studies, 4, 20-29.

Johanson, J., and J.-E. Vahlne (1990), The mechanism of internationalization, International Marketing Review, 7(4), 11-24.

Kiefer, M. N. (1988), Economic Duration Data and Hazard Functions, Journal of Economic Literature, 26, 646-579.

Mata, J. and P. Portugal (1994), Life Duration of New Firms, Journal of Industrial Economics, 27, 227-246.

Oviatt, B. M. and P. P. MacDougall (1994), Toward a Theory of International New Ventures, Journal of International Business Studies, 25(1), 45-64.

Pennings, E. and L. Sleuwaegen (1998), The Choice and Timing of Foreign Market Entry under Uncertainty, Departement Toegepaste Economische Wetenschappen, Onderzoeksrapport Nr. 9826, Katholieke Universiteit Leuven.

Rivoli, P. and E. Salorio (1996), Foreign Direct Investment and Investment under Uncertainty, Journal of International Business Studies, 27, 335-357.

Schoonhoven, C. B., K. M. Eisenhardt and K. Lyman (1990), Speeding Products to Market: Waiting Time to First Product Introduction in New Firms, Administrative Science Quarterly, 35, 177-207.

Tan, B., and I. Vertinsky (1996), Foreign direct investment by Japanese electronics firms in the United States and Canada: Modelling the timing of entry, Journal of International Business Studies, 27(4), 655-681. 